\title{
HUBUNGAN IKLIM KELAS DAN MOTIVASI BELAJAR DENGAN HASIL BELAJAR PESERTA DIDIK
}

\author{
Bradley Setiyadi $^{\left.a^{*}\right)}$, Lucia Loviansi $^{a)}$ \\ a) Universitas Jambi, Jambi, Indonesia \\ *)e-mail korespondensi: bradleysetiyadi@unja.ac.id
}

riwayat artikel : diterima: 19 November 2019; direvisi: 26 Desember 2019; disetujui: 16 Januari 2020

\begin{abstract}
Abstrak. Penelitian ini memiliki tujuan untuk melihat hubungan iklim kelas dan motivasi belajar dengan hasil belajar peserta didik Kelas XI Jurusan Administrasi Perkantoran SMK Negeri 1 Kota Jambi.Penelitian menggunakan metode kuantitatif dengan rancangan ex-post facto. Populasi penelitian adalah peserta didik Kelas XI Administrasi Perkantoran SMK Negeri 1 Kota Jambi, sebanyak 122 orang peserta didik, dan sampel yang dipilih 67 orang peserta didik berdasarkan perhitungan intrapolasi selanjutnya pembagian sampel menggunakan Simple Random Sampling. Teknik pengumpulan data dalam penelitian ini menggunakan data-data primer berupa angket dan data-data sekunder berupa data nilai rata-rata harian hasil ulangan peserta didik. Teknik analisa data yang digunakan dalam penelitian ini adalah teknik analisis korelasi sederhana dan analisis korelasi berganda. Hasil dari penelitian menunjukan bahwa: (1) Terdapat hubungan iklim kelas dengan hasil belajar peserta didik dengan kekuatan hubungan 0,595 ( $\rho<0.01$ ), (2) Terdapat hubungan motivasi belajar dengan hasil belajar peserta didik, dengan ekuatan hubungan $0,744((\rho<0.01)$,dan $(3)$ Terdapat hubungan iklim kelas dan motivasi belajar dengan hasil belajar peserta didik dengan kekuatan hubungan sebesar 0,783. Dapat disimpulkan iklim kelas dan motivasi belajar secara bersama-sama memiliki korelasi dengan hasil belajar peserta didik. Kesimpulan ini menyarankan agar pendidik dapat mengoptimalkan kelas dan memberikan kesadaran akan pentingnya belajar serta memotivasi peserta didik saat proses pembelajaran berlangsung, dengan menciptakan suasana kelas yang kondusif dan memberikan metode pembelajaran yang menarik supaya peserta didik tidak merasa jenuh dan bosan, serta merasa aman dan nyaman dan bersemangat dalam belajar di kelas sehinga akan berimplikasi pada hasil belajar yang maksimal.
\end{abstract}

Kata Kunci: Iklim Kelas, Motivasi Belajar dan Hasil Belajar Peserta didik.

\section{THE RELATIONSHIP BETWEEN CLASSROOM CLIMATE AND LEARNING MOTIVATION WITH STUDENT LEARNING OUTCOMES}

\begin{abstract}
This study aims to look at the relationship between classroom climate and learning motivation with student learning outcomes in Class XI Office Administration at SMK Negeri 1 Kota Jambi. This study uses quantitative methods with ex post facto design. The population used in this study were students of Class XI Office Administration at SMK Negeri 1 Kota Jambi. The study population was 122 students and the sample chosen was 67 students based on intrapolation calculations and then the distribution of samples using Simple Random Sampling. Data collection techniques in this study used primary data in the form of a questionnaire and secondary data in the form of data on the average value of student tests. Data analysis techniques used in this study are simple correlation analysis and multiple correlation analysis. The results showed that: (1) There was a relationship between classroom climate and student learning outcomes of 0.595 with a percentage of $59.5 \%$ and a significance value of 0.000 so that rcount $>$ rtable or 0.595> 0.201 could be said to be significant. Because $r$ count> $r$ table then Ho is rejected and Ha is accepted. (2) There is a relationship of learning motivation with student learning outcomes of 0.744 with a percentage of $74.4 \%$ and a significance value of 0.000 so that rcount> rtable or $0.744>0.201$ can be said to be significant. Because $r$ count> $r$ table then Ho is rejected and Ha is accepted; and (3) There is a relationship between classroom climate and learning motivation with student learning outcomes of 0.783 with a percentage of $78.3 \%$. It can be concluded that classroom climate and learning motivation together have a correlation with student learning outcomes. This conclusion suggests that educators can optimize classrooms and provide awareness of the importance of learning and motivate students during the learning process, by creating a conducive classroom atmosphere and providing interesting learning methods so that students do not feel bored and bored, and feel safe and comfortable and excited in learning in class so that it will have implications for maximum learning outcomes.
\end{abstract}

Keywords: classroom climate; learning motivation; student learning outcomes

\section{PENDAHULUAN}

Fungsi pendidikan nasional menurut UU Sisdiknas No. 20 Tahun 2003 adalah mewujudkan manusia yang beriman, berakhlak mulia, sehat, berilmu, cakap, kreatif, mandiri dan bertanggung jawab dengan cara mengembangkan potensi peserta didik. Keberhasilan proses pendidikan menunjukan bahwa Tujuan pendidikan nasional dikatakan tercapai yang dapat dilihat dari nilai hasil evaluasi belajar peserta didik, baik evaluasi harian (formatif), tengah dan akhir semester atau hasil Ujian Nasional. Evaluasi dinyatakan sebagai suatu proses sistematis dalam menentukan tingkat pencapaian tujuan instruksional dan 
meruakan sarana yang penting dalam meraih tujuan pembelajaran (Ratumanan dikutip Ardiyanto, Winarno \& Adi, 2016). Menurut Sardiman (2014), tujuan instruksional umum dirumuskan dengan hasil belajar yang pencapaiannya berwujud pembentukan watak peserta didik secara bertahap, kemampuan berpikir dan peguasaan keterampilan teknologi. Cara mengetahui sejauh mana peserta didik telah menguasai suatu kompetensi dasar tertentu dapat dilakukan dengan menilai hasil dari proses pembelajaran. Tujuan dari penilaian hasil berlajar secara lebih spesifik adalah untuk mendiagnosa kesulitan belajar peserta didik, mengukur pertumbuhan dan perkembangan peserta didik, mengetahui tingkat pencapaian kompetensi peserta didik serta untuk memperoleh masukan atau umpan balik bagi pendidik dan peserta didik dalam rangka perbaikan dari proses pembelajaran. (Anonim, 2005).

Belajar merupakan sebuah proses sehingga setelah peserta didik mengikuti rangkaian proses pembelajaran, maka hasul belajar didapakan. Proses belajar mengajar yang dialamiperserta didik memberikan pengaruh terhadap hasil belajar yang didapatkan. Menurut Sudjana (2005), hasil belajar yang didapatkan oleh peserta didik dipengaruhi oleh dua faktor utama, yakni faktor dari dalam diri peserta didik dan faktor yang datang dari luar peserta didik, artinya dipengaruhi oleh kempuan peserta didik itu sendiri dan juga dari lingkungan yang menyertainya. Menurut Clark dikutip Hadiyanto (2016), lingkungan belajar mempengaruhi 30\% hasil belajar peserta didik dimana yang paling dominan adalah kualitas pengajaran di dalam kelas.

Karakteristik atau iklim kelas berperan dan berpengaruh terhadap kualitas pengajaran sehingga berimplikasi pada hasil belajar yang baik. Menurut Kadarsih, Ramses \& Efendi (2016), kegiatan pembelajaran di dalam kelas ditunjang oleh faktor ikilim kelas. Kualitas pembelajaran akan tercipta jika didukung oleh Iklim kelas atau suasana kelas yang kondusif. Sebaliknya, kondisi kelas yang kurang baik akan mengganggu proses pembelajaran yang dilakukan di dalam kelas. Pada titik ini, peranan dari pendidik sangat penting dalam upaya mengatur kegiatan pembelajaran di kelas. Karenanya perlu diupayakan menciptakan kondisi kelas yang kondusif yang menunjang hasil dari proses pembelajaran peserta didik.

Keberhasilan pembelajaran peserta didik, juga ditentukan oleh faktor dari dalam, yaitu motivasi belajarnya. Peserta didik dengan motivasi tinggi dapat menumbuhkan energi positif dalam dirinyauntuk mencapai hasil belajar yang baik. Seseorang yang cenderung berusaha menyelesaikan tugasnya secara tuntas, dengan tanpa menunda-nunda pekerjaannya berarti memiliki motif berprestasi yang tinggi. (Uno, 2016). Hasil belajar yang optimal diwujudkan dari semangat berprestasi yang tinggi dan sebaliknya apabila hasil belajar yang tidak memuaskan disebabkan oleh semangat berprestasi yang rendah. Tingkat keberhasilan atau kegagalan belajar peserta didik sangat ditentukan oleh motivasi. Seseorang yang tidak optimal melakukan aktivitas belaja berarti tidak mempunyai motivasi dalam belajar. Selain itu, usaha pencapaian prestasi didorong oleh motivasi yang berfungsi sebagai pendorong dalam upaya untuk mencapai hasil yang diinginkan. Hasil belajar yang baik diarahkan oleh motivasi yang tinggi. Motivasi adalah suatu energi pengarah dan pengerak yang memperkuat tingkah laku. Motivasi terdiri dari motivasi intrinsik (dari dalam individu) serta motivasi ekstrinsik (dari luar individu). Karena pentingnya motivasi, maka diperlukan upaya nyata agar peserta didik bangkit semangat belajarnya sehingga tujuan pembelajaran yang dikehendaki dapat tercapai. (Kompri, 2016).

Suasana atau iklim kelas yang kondusif akan mampu menciptakan proses pembelajaran yang ideal yang pada akhirnya dapat mendukung terciptanya kualitas proses pembelajaran yang diharapkan. Akan tetapi, proses pembelajaran yang terjadi selama ini masih berpusat pada pendidik sehingga cenderung berjalan satu arah. Selain itu, proses pembelajaran yang ada kurang memperhatikan partisipasi aktif peserta didik sehingga peserta didik merasakan bahwa pembelajaran yang ada menjadi kurang bermakna. Ditambah lagi kegiatan pembelajaran belum sepenuhnya mampu mengembangkan potensi dari peserta didik secara optimal. Kegiatan pembelajaran di kelas (sekolah) hendaknya bukan hanya mementingkan materi ajar, atau siapa yang mengajar, melainkan bagaimana materi tersebut diajarkan.

Berdasarkan gambaran tersebut, sekolah perlu meningkatkan hasil belajar peserta didik dengan mengoptimalkan suasana atau iklim kelas yang selalu kondusif sehingga dapat mempelancar kegiatan belajar mengajar. Karenanya perlu dilakukan kajian untuk melihat apa yang bisa mendukung hasil belajar dari peserta didik agar meningkat. Iklim kelas dipilih karena merupakan salah satu dari faktor eksternal yang paling dominan dalam mempengaruhi dan menentukan hasil belajar peserta didik. Kelas adalah tempat terjadinya interaksi antar anggota kelas, baik antar peserta didik maupun interakasi antara pendidik dengan peserta didik, yang karenanya menarik untuk diteliti. Pemahaman konsep dan Keterampilan Proses meningkat setelah siswa mengalami proses pembelajaran (Suchyadi \& Karmila, 2019). Motivasi belajar adalah bagian internal yang diduga kuat mendukung proses dan hasil belajar sehingga kajian aspek internal ini diharapkan akan lebih melengkapi keseluruhan hasil penelitian.

SMK Negeri 1 Kota Jambi merupakan salah satu sekolah yang unggul yang ada di Kota Jambi dengan Akreditasi "A", dengan beberapa pilihan jurusan seperti Akuntansi, Pemasaran, Teknik Komputer Jaringan dan Administrasi Perkantoran. Ruang lingkup penelitian ini adalah jurusan Administrasi Perkantoran. Berdasarkan pengamatan awal di SMK Negeri 1 Kota Jambi, yang terkait dengan iklim kelas dan motivasi belajar peserta didik dengan hasil belajar peserta didik, ditemukan fenomena yang mendorong dilaksanakannya penelitian ini. Bidang studi yang menjadi fokus pada peneltian ini adalah Otomatisasi Humas dan Keprotokolan karena masih terdapat beberapa peserta didik yang mendapatkan nilai dibawah KKM (Kriteria Ketuntasan Minimum) yaitu sebanyak 13 orang peserta didik. Fenomena yang ada antara lain ditemukannya suasana pembelajaran di kelas masih belum cukup kondusif dikarenakan masih ada peserta didik yang berbuat gaduh serta berbicara dengan teman lainnya sehingga kurang memperhatikan pendidik saat proses pembelajaran. Terlihat bahwa hubungan antar peserta didik terkesan kurang baik, karena di dalam kelas terjadi situasi dimana peserta didik membentuk kelompok sendiri 
yang mengakibatkan kurangnya interaksi yang timbul antar peserta didik. Beberapa kelompok peserta didik juga merasa bosan dan tidak bersemangat saat pembelajaran karena kurangnya variasi mengajar pendidik. Terdapat pula kelompok peserta didik yang tidak menggunakan jam kosong dengan membaca buku di perpustakaan. Jika hal ini dilakukan terus menerus akan berimplikasi nantinya dengan hasil dari proses pembelajaran yang diperoleh peserta didik.

Perubahan sikap, perilaku dan keterampilan peserta didik adalah esensi dari hasil belajar. (Supardi, 2015). Sudjana (2014) mengemukakan, setelah peserta didik menerima pengalaman belajarnya, maka akan timbul kemampuan untuk mendapatkan hasil dari proses belajar mengajar. Senada dengan pendapat demikian, Sukmadinata (2011), kecakapan-kecakapan potensial yang dimiliki peserta didik akan menimbulkan kemampuan-kemampuan yang direalisasikan oleh hasil belajar.

Faktor internal dan eksternal serta faktor dari dalam proses pembelajaran memiliki peran dalam meningkatkan hasil belajar peserta didik. Menurut Clark dikutip Hadiyanto (2016), hasil belajar peserta didik dipengaruhi oleh faktor lingkungan sebesar 30\% dan faktor kemampuan peserta didik sebesar 70\%. Artinya, dalam menentukan atau memengaruhi hasil belajar yang dicapai, masih ada faktor-faktor dari luar yang berpengaruh, selain faktor daro dalam peserta didik itu sendiri. Kualitas pengajaran, yang didalamnya termasuk karakteristik atau iklim kelas, merupakan salah satu lingkungan belajar yang paling dominan memengaruhi hasil belajar peserta didik.

Motivasi belajar merupakan salah satu faktor internal yang mempengaruhi hasil belajar peserta didik. Dalam usaha mencapai hasil belajar yang tinggi, peranan motivasi belajar sangat penting bagi peserta didik. Pendidik akan menggambarkan peserta didik sebagai anak yang baik jika memiliki motivasi belajar yang tinggi, yang ditandai dengan kegairahannya dalam mengikuti proses pembelajaran, misalnya dengan melakukan belajar mandiri tanpa diperintah, baik di rumah, di sekolah maupun di saat-saat istirahat dimana tidak ada jam kelas pembelajaran. (Kompri, 2016). Dengan demikian, motivasi sangat menentukan hasil belajar peserta didik.

Hamalik dikutip Kompri (2016) mengemukakan, berhasil atau gagalnya perbuatan belajar peserta didik sangat ditentukan oleh motivasi. Peserta didik tidak akan mungkin maksimal dalam melakukan aktivitas belajar jika tidak memiliki motivasi belajar, sehingga akan sulit meraih hasil belajar yang diharapkan. Hal ini dikarenakan aktivitas belajar tersebut tidak menyentuh kebutuhan peserta didik. Tinggi rendahnya motivasi selalu dijadikan indikator baik buruknya prestasi belajar sehingga dapat disimpulkan bahwa prestasi belajar dipengaruhi oleh motivasi. (Wahab 2015).

Menurut Djamarah (2008:149), motivasi belajar dapat berada dalam diri peserta didik (motivasi intrinsik) serta berasal dari luar diri peserta didik tersebut (motivasi ekstrinsik).. Menurut Sardiman (2014), motivasi akan membuat hasil belajar menjadi optimal karena intensitas usaha belajar dan keberhasilan proses pembelajaran peserta didik ditentukan oleh ketepatan dari motivasi yang diberikan.

Iklim kelas merupakan suasana yang ditandai oleh adanya pola interaksi atau komunikasi antara pendidik-peserta didik, peserta didik-pendidik dan peserta didik-peserta didik yang kesemuanya itu berhubungan dengan kegiatan belajar mengajar. Nasution (2003: 119-120), mengemukakan berdasarkan sikap pendidik terhadap peserta didik dalam mengajarkan materi pembelajaran maka terdapat tiga jenis suasana yang dihadapi peserta didik dalam proses pembelajaran, yaitu:

1) Suasana kelas dengan sikap pendidik yang otoriter.

Suasana ini terjadi jika untuk mencapai tujuannya, pendidik menggunakan kekuasaan yang dimilikinya tanpa mempertimbangkan akibatnya bagi perkembangan peserta didik. Misalnya dengan paksaan untuk menguasai bahan pelajaran yag dianggap perlu untuk nilai ujian melalui hukuman dan ancaman.

2) Suasana kelas dengan sikap pendidik yang permisif.

Suasana ini ditandai dengan pemberian pelajaran yang selalu dibuat menyenangkan sementara peserta didik diberikan kebebasan tanpa banyak perintah dan larangan. Sikap ini mengutamakan perkembangan pribadi peserta didik dalam aspek emosional, agar terbebas dari kegoncangan jiwa serta dapat menyesuaikan diri dengan lingkungannya, sementara pendidik memposisikan diri berada di belakang peserta didik untuk member bantuan bila diperlukan.

3) Suasana kelas dengan sikap pendidik yang riil.

Suasana ini ditandai dengan diberikannya kesempatan bagi peserta didik untuk mendapatkan kebebasan tanpa pengawasan dan pengaturan yang ketat, namun tetap dalam pengendalian. Pendidik memberikan tugas kepada pserta didik dengan petunjuk dan pengawasan yang jelas, sementara peserta didik diberi kebebasan mengerjakan tugas tersebut sesuai denganpotensi yang ada pada dirinya.

Oleh karena itu, iklim yang kondusif dapat berimplikasi pada hasil belajar peserta didik karena peserta didik merasa aman dan nyaman dalam mengikuti proses kegiatan belajar mengajar. Motivasi belajar yang tinggi akan memiliki peluang yang besar dalam memperoleh hasil belajar yang optimal karena peserta didik akan melakukan kegiatan belajar mengajar dengan sangat bergairah dan semangat dalam mengikuti proses pembelajaran.

\section{METODE PENELITIAN}

Penelitian ini adala penelitian korelasional yang memiliki tujuan untuk mengetahui hubungan iklim kelas dan motivasi belajar dengan hasil belajar peserta didik Kelas XI (Sebelas) Jurusan Administrasi Perkantoran di SMK Negeri 1 Kota Jambi. Sedangkan desain penelitian digunakan adalah ex-post facto karena penelitian ini dimaksudkan untuk mengungkap peristiwa 
yang terjadi disertai dengan berbagai faktor yang dapat menimbulkan kejadian tersebut tanpa dilakukan manipulasi terhadap variabel yang akan diteliti.

Populasi penelitian ini harus bersifat homogen karena karakteristik populasi berstatus sama yaitu peserta didik yang mempelajari bidang studi Otomatisasi Tata Kelola Humas dan Keprotokolan dengan tidak memperhatikan golongan, etnis dan sosial. Populasi dalam penelitian adalah peserta didik kelas XI Jurusan Administrasi Perkantoran SMK Negeri 1 Kota Jambi yang terdiri dari 4 rombel (rombongan belajar) dengan jumlah populasi 122 peserta didik dan sampel terpilih sebanyak 67 peserta didik kelas XI Jurusan Administrasi Perkantoran SMK Negeri 1 Kota Jambi. Sampel atau responden dipilih secara simple random sampling atau acak sederhana.

Teknik pengumpulan data dalam penelitian ini menggunakan angket dan dokumentasi. Angke ditujukan untuk menggali iklim kelas dan motivasi belajar, sedangkan dokumentasi untuk mendapat informasi mengenai jumlah peserta didik dan data penilaian harian rata-rata peserta didik bidang studi Otomatisasi Tata Kelola Humas dan Keprotokolan pada Semester Ganjil Tahun Ajaran 2018/2019 Kelas XI Jurusan Administrasi Perkantoran SMK Negeri 1 Kota Jambi.

Validasi instrumen dilakukan melalui uji coba kepada peserta didik kelas XI Jurusan Administrasi Perkantoran yang berjumlah 30 orang dari luar sampel, hasilnya diperoleh 23 item valid untuk kuesioner iklim kelas, dan 22 item valid untuk kuesioner motivasi belajar. Analisis data yang dilakukan menggunakan analisis statistik deskriptif serta analisis korelasi sederhana dan berganda.

\section{HASIL DAN PEMBAHASAN}

Dari hasil pengambilan data yang didapatkan di lapangan terlihat bahwa untuk variabel iklim kelas, 19 responden $(28,36 \%)$ menyatakan bahwaiklim kelas baik, 25 peserta didik $(37,31 \%)$ menyatakan iklim kelassedang, dan 23 peserta didik $(34,33 \%)$ menyatakan iklim kelas buruk.Untuk variabel motivasi belajar dari 67 responden, sebanyak 15 responden (22,39\%) menyatakan bahwa motivasi belajar tinggi, 27 responden (40,30\%) menyatakan motivasi belajar sedang, dan 25 responden $(37,31 \%)$ menyatakan motivasi belajar rendah.

Untuk variabel hasil belajar peserta didik diperoleh bahwa dari 67 peserta didik kelas XIAdministrasi Perkantoran SMK Negeri 1 Kota Jambi tidak ada peserta didik yangmemperoleh hasil belajar dengan predikat sangat baik (0\%),sebanyak 56 orang peserta didik $(83,58 \%)$ memperoleh hasil belajar baik,11 orang peserta didik $(16,42 \%)$ memperoleh hasil belajar dengan predikat cukup, dan tidak ada peserta didik mendapatkan hasil belajar denganpredikat kurang $(0 \%)$.

Dari hasil pengambilan data yang ada diketahui bahwa hubungan iklim kelasdengan hasil belajar peserta didik sebesar $0,595(\rho<0.05)$ signifikan dengan kekuatan hubungan sedang. Korelasi secara parsial menunjukkankontribusi variabel iklim kelas terhadap hasil belajar adalah 59,5\%. Hubungan antara motivasi belajar dengan hasil belajarpeserta didik sebesar 0,744 $(\rho<0.05)$. Korelasi secara parsial variabel motivasi belajar dengan hasil belajar adalah74,4\%. Hasil dari perhitungan korelasi ganda menunjukkan terdapat korelasi antara variabel iklim kelas dan motivasi belajar secara bersama-sama denganhasil belajar peserta didik dengan sebesar 0,783, hal ini menunjukkan bahwa terdapathubungan yang kuat, sehingga dapat disimpulkan iklim kelas dan motivasi belajar secara bersama-sama memiliki kontribusi terhadap variasihasil belajar peserta didik.

Nilai korelasi antara variabel iklim kelas dan hasil belajar adalah sebesar 0,595 bermakna terdapat hubungan pada kategori sedang antara variabel iklim kelas dengan hasil belajar peserta didik. Korelasi secara parsial variabel iklim kelas dengan hasil belajar adalah 59,5\%. Sehingga dapat disimpulkan iklim memiliki korelasi dengan hasil belajar peserta didik. Iklim kelas merupakan suasana atau kondisi yang terjadi di dalam kelas yang mendukung proses pembelajaran, dimana iklim kelas yang baik dapat mendukung terjadinya proses pembelajaran yang baik yang secara langsung berimplikasi pada pencapaian hasil belajar yang baik pula. Hal ini sesuai dengan pendapat Clack yang dikutip Hadiyanto (2016), yang mengemukakan bahwa kemampuan peserta didik dan lingkungan mempengaruhi hasil belajar peserta didik di sekolah. Kualitas pengajaran merupakan faktor lingkungan belajar yang paling dominan mempengaruhi hasil belajar di sekolah, sehingga dalam hal ini semakin baik hasil belajar menunjukkan semakin baik pula kualitas pengajarannya. Temuan penelitian ini bersesuaian dengan hasil penelitian yang dilakukan oleh Wening Kadarsih, Ramses, Yarsi Efendi (2016), dan dengan hasil penelitian Muhammad Fauzie (2014), yang menyatakan iklim atau suasana kelas memiliki hubungan yang kuat dengan hasil dan prestasi belajar peserta didik dalam bidang studi tertentu.

Temuan berikutnya, nilai korelasi antara variabel motivasi belajar dengan hasil belajar adalah sebesar 0,744 , menunjukkan interprestasi hubungan kuat antara variabel motivasi belajar dan hasil belajar peserta didik sehingga dapat disimpulkan bahwa hasil belajar dapat ditingkatkan dengan meningkatkan motivasi belajar karena motivasi merupakan dorongan dari dalam diri seseorang untuk berbuat atau melakukan sesuatu dalam mencapai tujuan. Oleh karena itu, motivasi belajar peserta didik yang tinggi dapat mempengaruhi pencapaian hasil belajar peserta didik. Hal ini bersesuaian dengan hasil penelitian Radinal Mukhtar (2015) dan Nur Yuliany (2018), yang mengemukakan bahwa terdapat hubungan yang positif dan signifikan antara motivasi belajar dengan hasil belajar .

Penelitian ini juga menjawab rumusan masalah ketiga dengan hasil skor korelasi 0,783, yang menunjukkan tingkat keandalan atau hubungan pada kategori tinggi, sehingga dapat disimpulkan bahwa variabel iklim atau suasana kelas secara bersama-sama dengan variabel motivasi belajar memiliki korelasi dengan hasil belajar peserta didik. Iklim kelas dan motivasi belajar peserta didik memiliki hubungan yang positif dengan hasil belajar peserta didik sesuai dengan pendapat Syah dikutip 
Wahab (2015), menjelaskan bahwa faktor yang secara langsung mempengaruhi hasil belajar peserta didik terdiri dari faktor eksternal yang berupa iklim kelas serta faktor internal dimana salah satunya adalah motivasi. Temuan penelitian ini menunjukkan bahwa iklim atau suasana kelas yang kondusif yang ditunjang dengan motivasi belajar yang tinggi akan menghaslkan hasil belajar yang optimal, sebaliknya, jika iklim kelas buruk dan motivasi belajar rendah akan berpengaruh terhadap rendahnya hasil belajar peserta didik.

\section{SIMPULAN}

Kesimpulan dari hasil penelitian ini adalah sebagai berikut:

1. Terdapat hubungan antara iklim kelas dan hasil belajar peserta didik Kelas XI Jurusan Administrasi Perkantoran SMK Negeri 1 Kota Jambi sebesar0,595 $(\rho<0,05)$. Nilai korelasi positif dengan kekuatan sedang. Dapat disimpulkan iklim memiliki korelasi dengan hasil belajar yang diperolah peserta didik.

2. Terdapat hubungan antara motivasi belajar dengan hasil belajar peserta didik Kelas XI Jurusan Administrasi Perkantoran SMK Negeri 1 Kota Jambi sebesar 0,744( $\rho<0,05)$.Nilai korelasi positif dengan tingkat kekuatan tinggi. Dapat disimpulkan motivasi belajar peserta didik memiliki korelasi dengan hasil belajar yang diperoleh peserta didik.

3. Terdapat hubungan antara iklim kelas dan motivasi belajar secara bersamaan dengan hasil belajar peserta didik kelas XI Jurusan Administrasi Perkantoran SMK Negeri 1 Kota Jambi dengan kekuatan sebesar 0,783, terkategori hubungan yang kuat. Dapat disimpulkan bahwa suasana atau iklim kelas dan motivasi belajar peserta didik secara bersamaan memiliki korelasi dengan hasil belajar yang diperoleh peserta didik.

Pendidik hendaknya menciptakan suasana kelas yang kondusif dan memberikan pembelajaran yang menarik supaya peserta didik tidak merasa jenuh dan bosan, sehingga peserta didik nyaman belajar di kelas dan bersemangat dalam belajar yang akan berimplikasi pada hasil belajar yang maksimal

\section{REFERENSI}

Anonim. (2005). Evaluasi hasil belajar. Jakarta: Depag RI Dirjen MP3A.

Ardyanto, E. R., Winarno, M.E \& Adi, S. (2016). Pengembangan instrumen pengetahuan bidang studi Pendidikan Jasmani Olahraga Kesehatan (PJOK) untuk Peserta didik Kelas XII Sekolah Menengah Atas. Jurnal Pendidikan: Teori, Penelitian dan Pengembangan. 1, 1897-1903.

Djamarah, S. (2008). Psikologi Belajar. Jakarta: Rineka Cipta.

Fauzie, Muhammad. (2014). Hubungan Iklim Kelas Dan Fasilitas Belajar Dengan Prestasi Belajar Ekonomi Siswa Kelas X Sma Negeri 3 Kisaran T.P 2013/2014. Universitas Negeri Medan

Hadiyanto. (2016). Teori dan pengembangan iklim kelas dan sekolah. Jakarta: Kencana.

Kadarsih. W., Ramses \& Efendi, Y. (2016). Hubungan iklim kelas dengan hasil belajar peserta didik Kelas XI SMAN 8 BATAM. SIMBIOSA, 5(1), 2301-9417.

Kompri. (2016). Motivasi pembelajaran perspektif pendidik dan peserta didik. Bandung: Remaja Rosdakarya.

Mukhtar, Radinal (2015) Hubungan Motivasi Belajar Dengan Hasil Belajar Pada Mata Pelajaran Seni Budaya Bidang Seni Musik Siswa Kelas X Sma Piri 1 Yogyakarta. thesis, Universitas Negeri Yogyakarta..

Nasution. (2003). Berbagai pendekatan dalam Proses belajar \& Mengajar. Jakarta: Bumi Aksara.

Sardiman, A. M. (2014). Interaksi dan motivasi belajar mengajar. Jakarta:Rajawali Pers.

Suchyadi, Y., \& Karmila, N. (2019). The Application Of Assignment Learning Group Methods Through Micro Scale Practicum To Improve Elementary School Teacher Study Program College Students ' Skills And Interests In Following Science Study Courses. JHSS (Journal of Humanities and Social Studies), 03(02), 95-98. https://doi.org/10.33751/jhss.v3i2.1466

Sudjana, N. (2005). Dasar-dasar proses belajar mengajar. Bandung: SinarBaru.

Sudjana, N. (2014). Penilaian hasil proses belajar mengajar. Bandung; PT. Remaja Rosdakarya Offset.

Sukmadinata, Nana Syaodih. (2011) Landasan Psikologi Proses Pendidikan.Bandung: Pemaja Rosdakarya

Supardi. (2015). Penilaian autentik pembelajaran afektif, kognitif dan psikomotorik: konsep dan aplikasi. Jakarta:Rajawali Pers. Uno, H. (2016). Teori motivasi dan pengukurannya. Jakarta: PT. Bumi Aksara.

Wahab, R. (2015). Psikologi belajar. Jakarta: Rajawali.

Yuliany, Nur, (2018). Hubungan Antara Motivasi Belajar Dan Hasil Belajar Siswa Sdn Emmy Saelan Makassar. Universitas Islam Negeri Alauddin Makassar, Indonesia Vol 5, No 2 